\title{
Posthypoxic cooling of neonatal rats provides protection against brain injury
}

\author{
Marianne Thoresen, Ralph Bågenholm, Else Marit Løberg, Fabio Apricena, \\ Ingemar Kjellmer
}

\begin{abstract}
Aim-To determine whether moderate hypothermia, applied after a hypoxicischaemic insult in neonatal rats, reduces cerebral damage.

Method-Unilateral hypoxic-ischaemic brain damage was induced in 7 day old rats by left carotid ligation, followed by 120 minutes of normothermic exposure to $8 \% \mathrm{O}_{2}$, followed by random selection to three hours of hypothermia (rectal temperature, mean (SD), $32.5(0.4)^{\circ} \mathrm{C}$ ) or normothermia $\left(38.3(0.4)^{\circ} \mathrm{C}\right)$. One hundred and one animals were used for brain temperature or blood chemistry studies and 24 for survival studies (7 days) with neuropathology, including cell counting as outcome measures.

Results-Thirty sections from each brain were histologically examined with respect to distribution and pattern of damage and given a score from 0 to 4 . Animals treated with hypothermia had significantly less damage than normothermic animals (score $0.5(0.3)$ vs $1.8(0.5))$.

Conclusions-Posthypoxic hypothermia reduces brain damage in awake, unrestrained 7 day old rats.

(Arch Dis Child 1996; 74: F3-F9)
\end{abstract}

Departments of

Paediatric and

Surgical Research,

University of Oslo, The

National Hospital,

Norway

Marianne Thoresen

Department of

Physiology, Division of

Perinatal Physiology

and Department of

Paediatrics I,

Göteborg University,

Sweden

Ralph Bågenholm

Ingemar Kjellmer

Department of Pathology, Division of Pathology, Divisio University of Oslo,

Ullevål University

Hospital

Else Marit Loberg

Fabio Apricena

Correspondence to:

Dr Marianne Thoresen,

Department of Paediatrics,

Ullevål Hospital, 0407 Oslo,

Norway.

Accepted 23 June 1995
Keywords: ischaemia, hypothermia, newborn, rat.

Despite advances in obstetrics, infants continue to be damaged by severe hypoxiaischaemia during labour and delivery. After initial cardiorespiratory resuscitation, there are no clinical interventions that have improved the outcome of the encephalopathy. ${ }^{12}$ It is clear that destructive processes continue to damage the brain for many hours after oxygenation and circulation have been restored. These processes involve calcium entry, oxygen free radicals, excitatory amino acids, proteolytic activation and immune/inflammatory activation.

Pharmacological treatment applied after the insult has provided partial neuroprotection (evaluated as a quantitative reduction in brain lesion) in an immature animal model. ${ }^{3}$ However, such intervention has not yet been investigated in humans and may have serious side effects in newborns. ${ }^{4}$
Reducing the cerebral temperature during hypoxia-ischaemia significantly protects the brain against damage in both humans and experimental animals ${ }^{5}$ and is a standard procedure during cardiac and neurosurgery. However, the possibility of reducing cerebral injury by cooling after a cerebral insult has not been so fully researched. Although not based on controlled studies, it was suggested in the 1960 s that infants cooled following birth asphyxia showed lower mortality and morbidity at 1 to 2 years of age. ${ }^{67}$ At the same time a study by Silverman suggested that premature infants had a higher mortality when nursed at $31.7^{\circ} \mathrm{C}$ incubator temperature for five days than at $33.3^{\circ} \mathrm{C},{ }^{8}$ and this significantly reduced the enthusiasm for cooling babies especially as no mechanistic framework then existed to explain any protective effect.

Hypothermia initiated after the insult has provided partial protection in some adult animal models, ${ }^{910}$ but not in others. ${ }^{11} 12$ In the immature rat subjected to three hours of mild or moderate hypothermia the treatment failed to show protection. ${ }^{13}$ However, in the newborn piglet, who has a more mature brain, 12 hours of mild posthypoxic-ischaemic hypothermia ameliorated delayed energy failure. ${ }^{14} \mathrm{We}$ set out to examine the effect of three hours of moderate hypothermia in the immature rat, paying particular attention to stable temperature and unrestrained experimental conditions.

\section{Methods}

The investigation was approved by the Göteborg University animal research ethics committee. On postnatal day 7 (day of birth designated day 0 ) a total of 12 SpragueDawley rat pups from 18 unrestricted litters were either used in temperature studies $(n=12)$, acute experiments for blood chemistry analysis $(n=77)$, or survival experiments after a hypoxic-ischaemic insult $(n=24) ; 39$ were excluded. There were no differences in weight or sex ratio in any of the three subgroups studied. The animals were kept under standard conditions. ${ }^{15}$

All pups except six unligated controls were anaesthetised with enflurane $(3 \cdot 0-3.5 \%$ for induction, $0.5-1.0 \%$ for maintenance) and oxygen:nitrous oxide 1:1. The left common 
carotid artery was ligated and cut between two ligatures. The duration of this operation varied between 4.5 and 7 minutes. Animals were excluded from the study if they weighed less than $9 \mathrm{~g}(\mathrm{n}=1)$ or there was bleeding during ligation $(n=2)$. Two animals ('probe animals') in each of the 18 litters held rectal probes (1 $\mathrm{mm}$ in outer diameter, inserted $0.75 \mathrm{~cm}$ and taped on to the tail) to monitor the temperature during the whole experimental period and they were later excluded.

Postoperatively, the pups were returned to the dam, and two hours after completion of the last operation the animals were subjected to hypoxia $\left(8 \% \mathrm{O}_{2}\right.$ in $\left.\mathrm{N}_{2}\right)$ in a double walled chamber (volume $4 \cdot 2$ litres). The air temperature was changed by a temperature regulated water jacket preset to give an air temperature of $36^{\circ} \mathrm{C}$ during the two hour long insult. All animals from the same litter were exposed simultaneously and in the same jar, except those used as controls who were not exposed to hypoxia. Immediately before exposure individual animals were paired for weight and within each pair randomly selected to be treated with either normal temperature (rectal temperature $38.5^{\circ} \mathrm{C}$ ) or hypothermia (rectal temperature $32.5^{\circ} \mathrm{C}$ ) for three hours directly following the insult. The probe animals from each litter (one to each temperature) were restrained in their movements so that the probe leads would not be entangled. The rest of the animals were allowed to move freely.

After hypoxia, half the litter was transferred to an identical pre-cooled jar (initial air temperature $15^{\circ} \mathrm{C}$ ) for induction of hypothermia. This reduced rectal temperature (mean (SD) to $32.5(0.7)^{\circ} \mathrm{C}$ within $18.4(6.5)$ minutes and this remained stable throughout. During steady hypothermia the air temperature was $29 \cdot 1(1 \cdot 2)^{\circ} \mathrm{C}$. The other half of the litter stayed in the original jar at normothermia where the hypoxic gas was changed back to air. After three hours of hypothermia or normal temperature, after a total period of separation of 5.5 hours, the pups were returned to the dam.

Twenty four animals survived to day 14 when they were anaesthetised with pentobarbital intraperitoneally 1-2 $\mathrm{mg}$ and the brains were perfusion fixed (transcardiac) with $4 \%$ phosphate buffered $(0 \cdot 1 \mathrm{M})$ formaldehyde for 15 minutes. The brains were left in situ at

Table 1 Definition of neuropathology grading

\begin{tabular}{|c|c|c|c|}
\hline Brain area & Grading & $\begin{array}{l}\text { Percentage } \\
\text { area affected }\end{array}$ & Morphological changes \\
\hline $\begin{array}{l}\text { Cortex, thalamus, } \\
\text { and basal ganglia }\end{array}$ & & $\begin{aligned} \leqslant & 10 \\
& 20-30 \\
& 40-60 \\
> & 75\end{aligned}$ & $\begin{array}{l}\text { Small, patchy, complete or incomplete infarcts } \\
\text { Partly confluent, complete, or incomplete infarcts } \\
\text { Large confluent complete infarcts } \\
\text { In cortex total disintegration of the tissue; in } \\
\text { thalamus and basal ganglia large complete } \\
\text { infarcts }\end{array}$ \\
\hline \multirow[t]{4}{*}{ Hippocampus ${ }^{\star}$} & 1 & $\leqslant 20$ & \multirow{4}{*}{$\begin{array}{l}\text { Necrotic neurons only in the most lateral areas - } \\
C A_{2} \text { and } C A_{3} \\
\text { Patchy areas of necrotic neurons in sectors } \\
C A_{1}-C_{4} \\
\text { More extensive areas of necrotic neurons in } \\
\text { sectors } \mathrm{CA}_{1}-\mathrm{CA}_{4} \\
\text { Complete infarction of hippocampus including } \\
\text { the dentate gyrus }\end{array}$} \\
\hline & 2 & 50 & \\
\hline & 3 & 75 & \\
\hline & 4 & 100 & \\
\hline
\end{tabular}

Grade 0 indicates no histopathological damage.

*The grading system is defined differently for grades $1-3$ in the hippocampus as selective neuronal necrosis is the typical damage in this area. $4^{\circ} \mathrm{C}$ for 24 hours before they were dissected out and kept in $4 \%$ formaldehyde until further processing. In 12 animals we recorded simultaneous brain and rectal temperatures. Under enflurane $/ \mathrm{N}_{2} \mathrm{O}$ anaesthesia, temperature sensors (type $\mathrm{K}$, chromel-alumel; $0.2 \mathrm{~mm}$ diameter) were inserted $2 \mathrm{~mm}$ into each hemisphere (aiming at the caudo-putamen). The sensors were fixed by tape on to an external frame. The positions of the sensors were confirmed at necropsy. A rectal sensor was inserted as described. The animals were taped on to a grid restricting neck and leg movements and allowed to stabilise for 60 minutes inside the jar before the start of hypoxia followed by hypothermia. Continuous recordings of rectal and bilateral hemispheric temperatures were stored (Lab-View, version 2.5.2 National Instruments, Austin, Texas, USA). The temperature sensors were calibrated against a precision mercury thermometer before and after every experiment. There was little $\left(<0.05^{\circ} \mathrm{C}\right)$ deviation in the values obtained.

Seventy seven animals were used to study blood chemistry changes at different points in time during the experiment when they were decapitated. Mixed arterial and venous blood samples from the neck were immediately obtained in duplicate. Blood gases were analysed (Radiometer ABL 510, Copenhagen, Denmark) in 13 controls (ligated $n=7$, unligated $n=6$ ) in eight animals after two hours of hypoxia, in eight after three hours at normal temperature, and in eight after three hours of hypothermia. Samples were analysed at body temperature. Glucose and lactate were examined in 10 control animals (ligated but no hypoxia) who were separated from the dam for five hours, and in 30 animals after the standardised insult followed by three hours of hypothermia $(n=15)$ or normal temperature $(n=15)$. Glucose and lactate were analysed by standard assays without deproteinisation (Hexokinase G6P-DH, Boehringer, Mannheim, Germany) and ultraviolet methods.

Coronal blocks through the brain were embedded in paraffin wax, subserially sectioned at $5 \mu \mathrm{m}$ and stained with haematoxylin and eosin. Thirty sections were examined from each brain. In five sections around the mid dorsal level, total cell counting in the hippocampus (area $\mathrm{CA}^{1-4}$ including gyrus dentatus) was also performed. The two examiners (EML and FA) were blinded to the mode of treatment.

The localisation of the brain damage obtained in the present study was the same as that found by Towfighi et al, ${ }^{16}$ who examined their rat pups 21 days after the insult. The pattern of damage followed predominantly the distribution of the middle cerebral artery. Typically, the lateral part of the hemisphere was the first to be affected. The predominant lesion in the present model was infarction, which after seven days of survival, before gliosis had developed, was seen as pale areas with vacuolisation of the neuropil and necrotic neurons with eosinophilic cytoplasm. The extent of this type of damage was graded from $0-4$, with 0.5 intervals for each of the four 


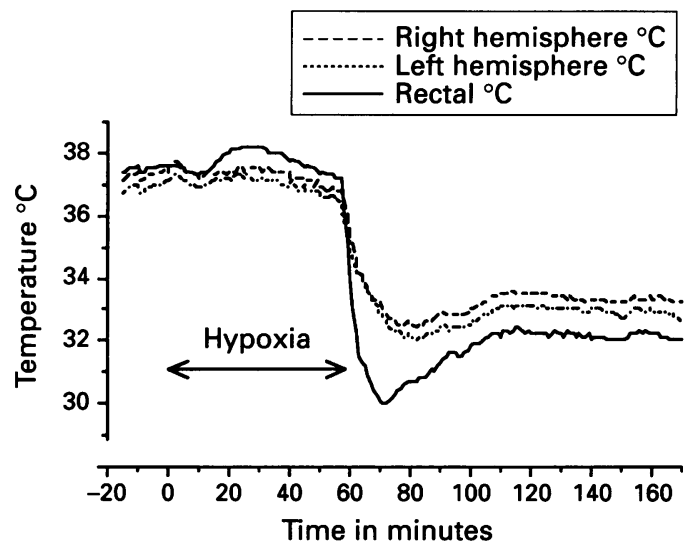

Figure 1 Simultaneous recordings of intracerebral temperatures from both hemispheres as well as rectal temperature in a 7 day old awake rat pup during 60 minutes of hypoxia $\left(8 \% \mathrm{O}_{2}\right)$ followed by 110 minutes of hypothermia. Zero time is the start of hypoxia.

regions - the cortex, hippocampus, basal ganglia and thalamus. The pathological scores for these areas are defined in table 1 . The term 'incomplete' infarct means a localised area where the neurons are mainly necrotic while the other tissue elements (such as glia and vessels) are preserved. In a completely infarcted area all tissue elements are damaged. The contralateral hemisphere was without damage in all animals.

Treatment groups were compared using the Wilcoxon matched pairs test. Blood chemistry values were compared using ANOVA followed by Student's $t$ test with Bonferroni correction when appropriate. A P value of less than 0.05 was regarded as significant. Individual brain and rectal temperatures were compared using Pearson's correlation coefficient. Pearson's correlation coefficient was also used for comparing cell counting and pathology scores in the hippocampus.

\section{Results}

Figure 1 shows brain temperature from both hemispheres (the left carotid artery was ligated) and rectal temperature in one rat pup during 60 minutes of hypoxia followed by 110 minutes of hypothermia. Figure $2 \mathrm{~A}$ shows the correlation $(r=0.99)$ between the right and left hemispheric temperature over a temperature range of $28-40^{\circ} \mathrm{C}$ during normoxia or hypoxia in 12 animals. In fig $2 \mathrm{~B}$, the correlation between the right hemispheric and rectal temperature in the same situations is displayed

Table 2 Blood gas analysis of mixed arterial and venous blood from four groups of 7 day old rats

\begin{tabular}{|c|c|c|c|c|}
\hline Condition & $\begin{array}{l}\text { Control* } \\
(n=13)\end{array}$ & $\begin{array}{l}\text { Hypoxia† } \\
(n=8)\end{array}$ & $\begin{array}{l}\text { Normal temp recovery } \neq \\
(n=8)\end{array}$ & $\begin{array}{l}\text { Hypothermic recovery } \\
(n=8)\end{array}$ \\
\hline $\begin{array}{l}\mathrm{pH} \\
\mathrm{PCO}_{2}(\mathrm{kPa}) \\
\mathrm{PO}_{2}(\mathrm{kPa}) \\
\text { aBE }(\mathrm{mmol} / \mathrm{)}) \\
\text { Haematocrit }\end{array}$ & $\begin{array}{c}7 \cdot 43(0 \cdot 05) \\
6 \cdot 5(0 \cdot 7) \\
9 \cdot 4(1 \cdot 7) \\
6 \cdot 7(5 \cdot 1) \\
29(2 \cdot 2)\end{array}$ & $\begin{array}{c}7 \cdot 31(0 \cdot 04)^{\mathrm{a}} \\
2 \cdot 7(0 \cdot 7)^{\mathrm{b}} \\
7 \cdot 2(2 \cdot 5) \\
-14 \cdot 3(5 \cdot 5)^{\mathrm{b}} \\
29 \cdot 2(1 \cdot 7)\end{array}$ & $\begin{array}{c}7.41(0.02) \\
4 \cdot 8(0 \cdot 5) \\
10 \cdot 2(0.7) \\
1.3(2 \cdot 3) \\
30.9(1 \cdot 1)\end{array}$ & $\begin{array}{c}7.38(0.02) \\
5.4(0.5) \\
10.6(1.9) \\
1.3(1.7) \\
29.9(1.2)\end{array}$ \\
\hline
\end{tabular}

Values are mean (SD); hypoxia vs control aP $<0.01$, bP $<0.001$.

* Seven were ligated and six unligated, values were pooled because there was no difference between the two groups; thypoxic animals after two hours of hypoxia; fnormal temperature recovery after three hours of posthypoxic normothermia; Thypothermia recovery after three hours of posthypoxic hypothermia.

No animals had rectal probes. showing a correlation of 0.96 between the two, hence rectal temperature is representative of brain temperature.

Blood gas values obtained before hypoxia (ligated and unligated animals), at the end of hypoxia and at the end of either normal temperature or hypothermia recovery are shown in table 2. The values reflect a considerable metabolic acidosis (base deficit $-14 \cdot 3$ $\mathrm{mmol} / \mathrm{l}$ ) and hyperventilation at the end of the hypoxic period. There was no difference in $\mathrm{pH}$, blood gas values, or haematocrit between the normal temperature and hypothermia animals at the end of the recovery period. Table 3 shows the glucose and lactate values for control animals which were separated from the dam for five hours and for animals treated with either normal temperature or hypothermia after hypoxia. There was a small but significant increase in glucose after hypothermia. In the surviving animals the body weight on day 14 was higher in hypothermic animals than normal temperature animals (24.4 $(2 \cdot 5) \mathrm{g}$ and $22.5(3.7) \mathrm{g}$, respectively; $\mathrm{P}<0.02$ ).

The definitions used for scoring the histological damage in each brain area are listed in table 1. Figure 3 shows the hippocampal pathology score (0-4) for each animal in the normal temperature $(n=12)$ and hypothermia groups $(n=12)$. The protective effect of three hours of hypothermia was significant. The
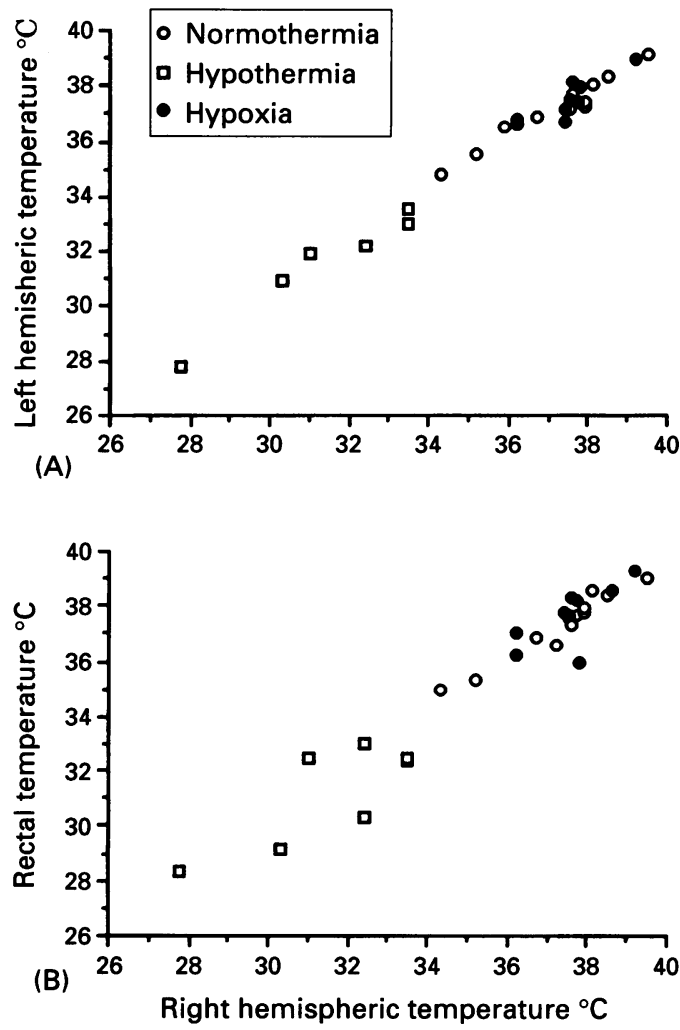

Figure 2 (A) shows the correlation between the right and left hemispheric temperatures $(r=0.99)$ obtained from 12 animals in three different situations: normoxic

normothermia (minimum 15 minutes), hypoxic normothermia (minimum 60 minutes), normoxic hypothermia (minimum 45 minutes). The mean values of the continuous recordings (sampled every minute) were compared. In (B) the correlation between the right hemispheric and the rectal temperature for the same situations is shown $(r=0.96)$. 
Table 3 Glucose and lactate analysis in three groups of animals

\begin{tabular}{|c|c|c|c|}
\hline Condition & $\begin{array}{l}\text { Control* } \\
(n=10)\end{array}$ & $\begin{array}{l}\text { Normothermia } \\
\text { recovery† } \\
(n=15)\end{array}$ & $\begin{array}{l}\text { Hypothermia } \\
\text { recovery } \ddagger \\
(n=15)\end{array}$ \\
\hline $\begin{array}{l}\text { Glucose }(\mathrm{mmol} / \mathrm{l}) \\
\text { Lactate }(\mathrm{mmo} / \mathrm{l})\end{array}$ & $\begin{array}{l}4.7(0.36) \\
1.2(0.18)\end{array}$ & $\begin{array}{l}4.5(0.66) \\
1.4(0.27)\end{array}$ & $\begin{array}{l}5.4(0.59)^{\star} \\
1.2(0.32)\end{array}$ \\
\hline
\end{tabular}

Values are mean (SD); hypothermia recovery $v s$ control $\mathrm{P}<0.01$.

*Ligated control (separated from the dam for five hours and no hypoxia; ttwo hours of hypoxia followed by three hours of normoxic normothermia; $\ddagger$ two hours of hypoxia followed by three hours of normoxic hypothermia.

damage score was reduced by $65 \%$ in the hypothermic animals compared to the normal temperature animals $(p<0.04)$. Within each group the distribution of damage between brain regions was very similar (fig 4 ). The cortex was significantly $(P<0.001)$ more damaged than the thalamus. The validity of the subjective pathology score was tested by comparing this score to total cell counting of damaged and normal cells in the hippocampus (fig 5) $(r=0.96)$. Histological examples of hypoxicischaemic damage of varying degree are shown in fig 6.

\section{Discussion}

Thirty years ago, cold water immersion of asphyxiated babies immediately after birth was reported to reduce mortality and morbidity. ${ }^{1718}$ However, these were uncontrolled studies. Neither clinical $^{8}$ nor experimental animal ${ }^{19}$ studies supported the idea of protection from hypothermia and the treatment was abandoned.

The clinical potential for hypothermia is obviously as a posthypoxic treatment. Recently, two randomised clinical trials in people with head injuries have demonstrated that 24 or 48 hours of mild hypothermia lessens brain injury. ${ }^{20} 21$ In a prospective study of adult stroke patients it was shown that increased temperature during the first 24 hours after the insult was the best predictor of adverse outcome. ${ }^{22}$

Because the newborn immature brain is different from the mature brain in many respects, investigations have to be carried out on newborn animal models. There are important differences with respect to neuronal proliferation, ongoing myelination, lower proportion of glial cells, ${ }^{23}$ maturation of different neurotransmitter systems, ${ }^{24}$ lower metabolic needs ${ }^{25}$

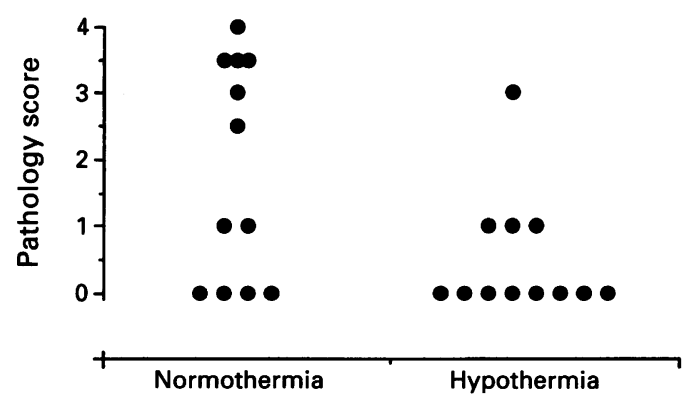

Figure 3 Hippocampal pathology score for the normothermic animals $(n=12)$ and for the hypothermic animals $(n=12) ; P \leqslant 0.04$.

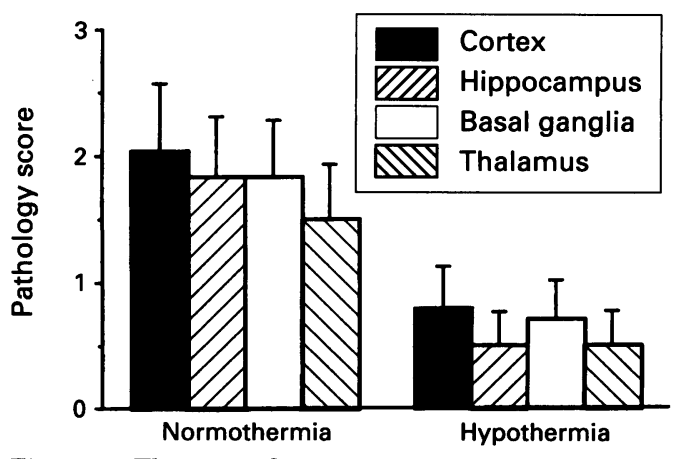

Figure 4 The mean (SEM) values of the pathology score obtained for each of the four regions in the left hemisphere.

and different substrate dependency. ${ }^{26}$ The response to ischaemia is also different in the immature brain: the injury is not enhanced by an increased blood glucose 27 as in the adult, the excitotoxicity to NMDA and AMPA glutamate receptors is higher in the immature brain than in the adult brain, ${ }^{28-30}$ the relative vulnerability of white matter is higher, ${ }^{16} 31$ and the inflammatory response/gliotic reactions seem to be different. ${ }^{32} 33$

A perinatal model of hypoxic-ischaemic brain damage that combines unilateral common carotid artery ligation and hypoxia ${ }^{34}$ has been much used in neuroprotection studies. ${ }^{15} 35$ The one published study on posthypoxic hypothermia in this model failed to show any neuroprotection, although cooling of either $3^{\circ} \mathrm{C}$ or $6^{\circ} \mathrm{C}$ started immediately after the insult and lasted for three hours in their study and every animal was restrained during the experiment due to a rectal temperature probe being in place. Immobilisation of awake animals stresses them and this might affect outcome. ${ }^{36}$

In the present study we reported the outcome in unrestrained animals randomly allocated to either hypothermia or normothermia after having been subjected to unilateral carotid ligation and the same hypoxic insult. Detailed neuropathology was carried out 7 days after the insult. We found significant protection from hypothermia - a $65 \%$ reduction in damage score. The mechanisms by which hypothermia excerts protection have been studied only during intra-ischaemic hypothermia. Suggested mechanisms include

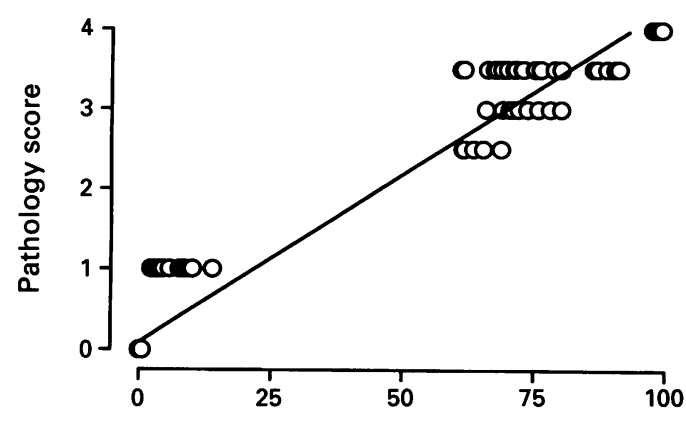

Percentage of necrotic cells in hippocampus

Figure 5 The pathology score in the left (ligated side) hippocampus vs the percentage of damaged cells obtained from total cell counting in five sections at the mid-dorsal level in each of the 24 animals. Linear regression, $r^{2}=0.96$ (95\% confidence interval 0.94-0.97). 

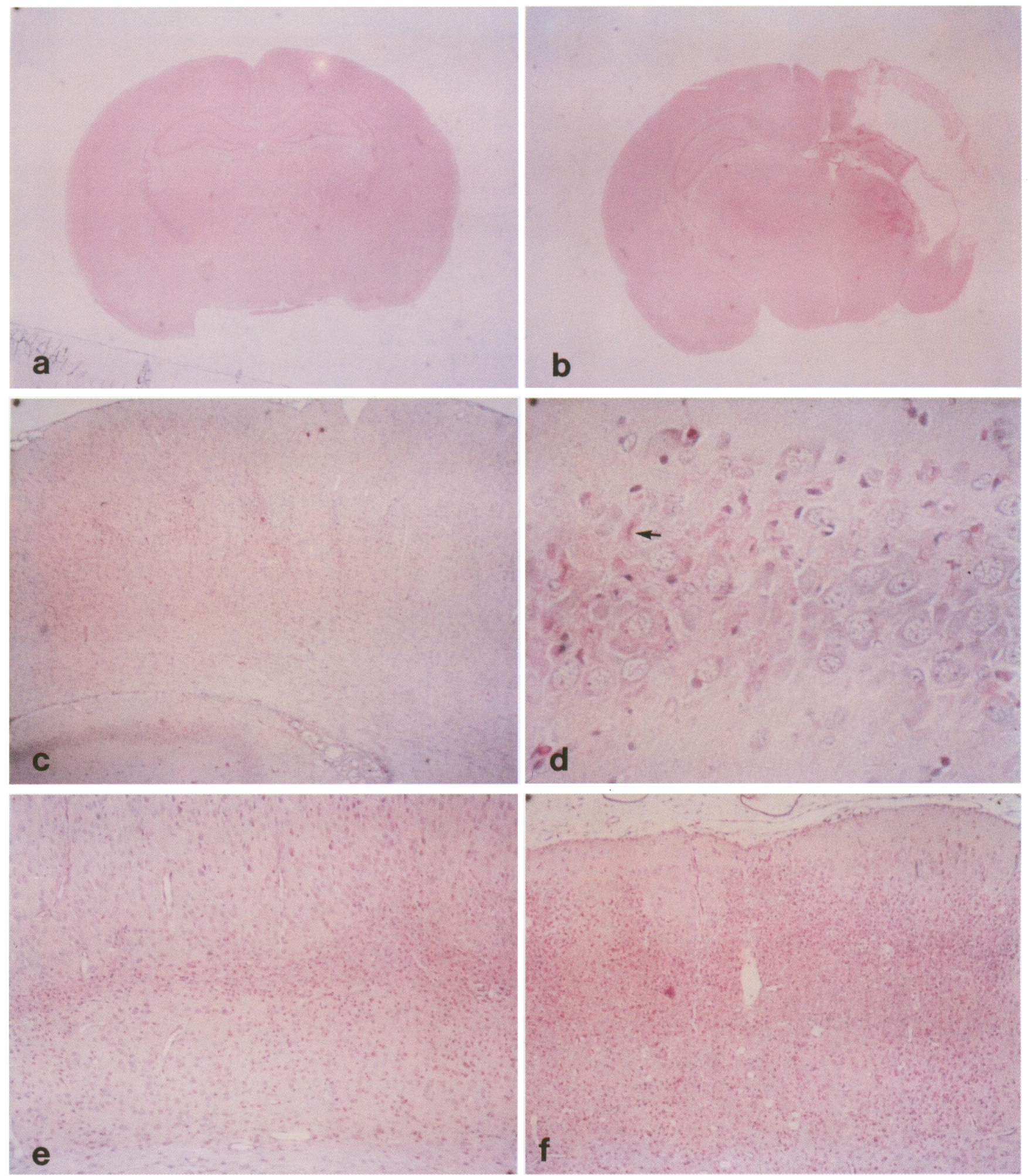

Figure $6 \mathrm{~A}$ Coronal section through the mid-dorsal level of the hippocampus. The left common carotid artery had been permanently ligated. No damage was visible at this magnification (haematoxylin and eosin). At higher magnification all areas except the thalamus (which was undamaged) had a pathology score of 1 (figs $6 C$ and D).

Figure $6 B$ Coronal section through the mid-dorsal level of the hippocampus. The left common carotid artery was ligated. Complete infarction was evident, with disintegration of cerebral tissue supplied by the left middle cerebral artery (haematoxylin and eosin). The pathology score for all areas except the thalamus (which was 3) was 4.

Figure 6C Small localised areas with necrotic neurons in cortex, grade 1 damage (haematoxylin and eosin).

Figure 6D Hippocampal damage (CA2-CA3) grade 1, necrotic neurons with eosinophilic cytoplasm (arrow) (haematoxylin and eosin).

Figure $6 E$ Cortex, grade 2 damage, with bandlike confluent infarcts in cortical layer 3 (haematoxylin and eosin).

Figure $6 F$ Cortex, grade 3 damage, with even more confluent infarcts, but no disintegration of the tissue (haematoxylin and eosin). 
inhibition of the production of oxygen free radicals, ${ }^{37}$ of excitatory amino acids, ${ }^{38}$ of lipid peroxidation $^{39}$ and postischaemic protein synthesis. ${ }^{40}$ Similar studies have not been performed during postischaemic hypothermia.

Small differences in temperature during hypoxic exposure are critical to the extent of brain damage. ${ }^{41}$ We have shown that in this model rectal temperature is representative of brain temperature and we always used two animals with a permanent rectal probe as the 'thermometer' for the litter. During the current series of insults the rectal temperature was $38.3^{\circ} \mathrm{C}$ which is considered to be in the upper normal range for rat pups. ${ }^{42}$ Using this level of temperature during the insult mimics the clinical situation of perinatal asphyxia, where the fetal temperature is higher than that of the mother during parturition. ${ }^{43}$

Hypothermia as treatment in this model implies separation from the dam for several hours and hypoglycaemia might cause additional damage. We therefore analysed blood glucose in treated and control animals and the concentrations were stable and normal during the whole study. Like others, ${ }^{44}$ we found a moderate increase in glucose in response to hypothermia. Lactate values were normal and did not differ from control values at the end of hypothermia or normal temperature periods. The substantial base deficit $(-14.3 \mathrm{mmol} / \mathrm{l})$ at the end of hypoxia was fully compensated after three hours of hypothermia or normal temperature.

We were intrigued that Yager and Vannucci, who used the same model, found no protection with mild or moderate hypothermia. ${ }^{13}$ A significant difference in the experimental conditions between their and our study was that all their animals had a rectal probe in situ and were restrained. We hypothesise that the effect of stress has modulated the protective effect of hypothermia. ${ }^{36}$

In this animal model of perinatal hypoxiaischemia different ways of assessment of brain damage have been used: macroscopic reduction in hemispheric size, ${ }^{45}$ morphological measurements of brain area, ${ }^{46}$ weight estimation $^{47}$ as well as a neuropathological scoring system based on the degree and distribution of neuronal damage. ${ }^{16} \mathrm{We}$ chose to do a detailed neuropathological assessment of the total hemisphere to evaluate the possibility of hypothermia changing the pattern and distribution of damage. This turned out not to be the case (fig 4). We used total cell counting in the hippocampus as a means of validating our pathology score. The subjective assessment and cell counting correlated well; $r=0.96$ (fig 5).

In conclusion, a reduction in rectal temperature of $6^{\circ} \mathrm{C}$, starting after the insult and lasting for three hours, offers substantial protection against damage in all regions of the brain of the neonatal rat. Recently, in a more mature animal model of posthypoxia-ischaemia, the newborn pig, ${ }^{48}$ we have also shown that 12 hours of mild posthypoxic hypothermia $\left(4^{\circ} \mathrm{C}\right.$ reduction) ameliorates secondary energy failure, as determined by ${ }^{31} \mathrm{P}$ magnetic resonance spectroscopy. ${ }^{49}$ Before starting clinical trials of hypothermia following birth asphyxia, more animal work is needed to define the optimal duration and the effective 'time window' for this treatment, as well as its possible adverse affects. Hypothermia immediately after resuscitation might allow time for pharmacological agents to enter the brain and work at an earlier stage of the posthypoxic cascade of damaging processes. We are grateful for support from The Norwegian Research Founcil, The University of Oslo Medical Faculty, The Laerdal The Swedish Medical Research Council (2591), the Free Masonry Orphanage Foundation, Göteborgs Läkarsallskap; Masonry Orphanage Foundation, Göteborgs Läkarsallskap; the Jerring, Samariten, Claes Groschinslcy Memorial,
Barnbördshuset Memorial, Âhlen and the General Maternity Hospital Foundations.

1 Levene MI. Management and outcome of birth asphyxia. In: Levene MI, Lilford RJ, eds. Fetal and neonatal neurology and neurosurgery. 2nd edn. Edinburgh: Churchill Livingstone, 1995: 427-43.

2 Whitelaw A. Intervention after birth asphyxia. Arch Dis Child 1989; 64: 66-8.

3 Wasterlain CG, Adams LM, Schwartz PH, Hattori H, Sofia RD, Wichmann JK. Posthypoxic treatment with felbamate is neuroprotective in a rat model of hypoxiaischemia. Neurology 1993; 43: 2303-10.

4 Levene MI, Gibson NA, Fenton AC, Papthoma E, Barnett $D$. The use of a Ca-channel blocker, Nicardipine, for severely asphyxiated newborn infants. Dev Med Child Neurol 1990; 32: 567-74.

5 Ginsberg MD, Sternau LL, Globus MY-T, Dietrich WD, Busto R. Therapeutic modulation of brain temperature: relevance to ischaemic brain injury. Cerebrovascular and Brain Metabolism Reviews 1992; 4: 189-225.

6 Miller JA jr. Hypotherrnia in the treatment of asphyxia. New York State f Med 1961; 61: 2954-65.

7 Westin B. Nyberg R, Miller JA, Wedenberg E. Hypothermia and transfusion with oxygenated blood in the treatment of asphyxia neonatorum. Acta Paediatr Scand 1962; 51: $1-80$.

8 Silverman WA, Fertig JW, Berger AP. The influence of the thermal environment upon the survival of newly born premature infants. Pediatrics 1958; 22: 876-86.

9 Busto R. Dietrich WD, Globus MYT, Ginsberg MD. Postischemic moderate hypotherrnia inhibits CAl hippocampal ischemic neuronal injury. Neurosci Lett 1989 101: 299-304.

10 Carroll M, Beck O. Protection against hippocampal CA1 cell loss by post-ischemic hypothermia is dependent on cell loss by post-ischemic hypothermia is dependent on
delay of initiation and duration. Metab Brain Dis 1992; 7: delay of

11 Welsh FA, Harris VA. Postischemic hypothermia fails to reduce ischemic injury in gerbil hippocampus. $f$ Cereb Blood Flow Metab 1991; 11: 617-20.

12 Dietrich WD, Busto R, Alonso O, Globus MY -T, Ginsberg MD. Intraischemic but not postischemic brain hypothermia protects chronically following global forebrain ischemia in rats. $\mathcal{F}$ Cereb Blood Flow Metab 1993; 13: 541-9.

13 Yager J, Towfighi J, Vannucci RC. Influence of mild hypothermia on hypoxic-ischemic brain damage in the immature rat. Ped Res 1993; 34: 525-9.

14 Thoresen M, Penrice J, Isrek A, Wyatt J, Cady EB, Wylezinska M, et al. Mild hypothermia following severe Wylezinska M, et al. Mild hypothermia following severe transient hypoxia-ischemia ameliorates delayed ('sec-
ondary') cerebral energy failure in the newborn piglet. Ped ondary') cerebral energy
Res $1995 ; 5: 667-70$.

15 Thordstein M, Bagenholm R, Thiringer K, Kjellmer I Scavengers of free oxygen radicals in combination with magnesium ameliorate perinatal hypoxic-ischemic brain damage in the rat. Ped Res 1993; 34: 23-6.

16 Towfighi J, Yager JY, Housman C, Vannucci RC. Neuropathology of remote hypoxicischemic damage in the immature rat. Acta Neuropathol 1991: 81: 578-87.

17 Westin B, Miller JA, Nyberg R, Wedenberg E. Neonatal asphyxia pallida treated with hypothemmia alone or with hypothemmia and transfusion of oxygenated blood. hypothemmia and transf

18 Cordey $R$. Hypothemmia in resuscitating newborns in white asphyxia. Obstet Gynecol 1964; 24: 760-7.

19 Oates RK, Harvey D. Failure of hypothermia as treatment for asphyxiated newborn rabbits. Arch Dis Child 1976; 51: 512-16.

20 Clifton GL, Allen S, Barrodale P, Plenger P, Berry J, Koch $S$, et al. A phase II study of moderate hypothemmia in severe brain injury. $\mathcal{F}$ Neurotrauma 1993; 10: 263-71.

21 Marion DW, Obrist WD, Carlier PM, Penrod LE, Darby JM. The use of moderate therapeutic hypothermia for patients with severe head iniuries - A preliminary report. f Neurosurg 1993; 79: 354-62.

22 Castillo J, Martinez F, Leira R, Prieto JM, Lema M, Noya $M$. Mortality and morbidity of acute cerebral infarction related to temperature and basal analytic parameters. Cerebrovasc Dis 1994; 4: 66-71. 
23 Samat HB. Substrates of maturation in the nervous system. In: Samat HB. Cerebral dysgenesis: embryology and clinical expression. Oxford: Oxford University Press, 1992: 1-473.

24 Swann JW, Brady RJ, Martin DL. Postnatal development of GABA-mediated synaptic inhibition in rat hippocampus. Neuroscience 1989; 28: 551-61.

25 Duffy TE, Nelson TR, Lowry OH. Cerebral carbohydrate metabolism during acute hypoxia and recovery. f Neurochem 1972; 19: 959-77.

26 Nehlig A, Pereira de Vasconcelos A. Glucose and ketone bodies utilization by the brain of neonatal rats. Progr Neurobiol 1993; 40: 163-221.

27 Vanucci RC, Yager JY. Glucose, lactic acid and perinatal hypoxic-ischemic brain damage. Pediatr Neurol 1992; 8: 3-12.

28 McDonald JW, Johnson MV. Physiological and pathophysiological roles of excitatory amino acids during central nervous system development. Brain Res Rev 1990; 15 41-70.

29 McDonald JW, Trescher WH, Johnston MV. Susceptibility of brain to AMPA induced excitotoxicity transiently peaks during early postnatal development. Brain Res 1992; 583: 54-70.

30 McDonald JW, Johnston MV. Physiological and patholog ical roles of excitatory amino acids during central nervous system development. Brain Res Rev 1990; 15: nervous

31 DeVries LS, Eken P, Groenendaal F, Vanhaastert IC Meiners LC. Correlation between the degree of periventricular leukomalacia diagnosed using cranial ultrasound and MRI later in infancy in children with cerebral palsy Neuropediatrics 1993; 9A: 263-8.

32 Morioka T, Streit WJ. Expression of immunomolecules on microglial cells following neonatal sciatic nerve axotomy. f Neuroimmunol 1991; 35: 21-30

33 McRae A, Gilland E, Bona E, Hagberg H. Microglia activation after neonatal hypoxicischemia. Dev Brain Res 1995; 84: 245-52.

34 Rice JEI, Vannucci RC, Brierley JB. The influence of immaturity on hypoxic-ischemic brain damage in the rat. Ann Neurol 1981; 9: 131-41.

35 Andine P, Lehmann A, Ellren K, Wennberg E, Kjellmer I Nielsen $\mathrm{T}$, et al. The excitatory amino acid antagonist kynurenic acid administered after hypoxic-ischemia in neonatal rats offers neuroprotection. Neurosci Lett 1988 90: 208-12.

36 Thoresen M, Bågenholm R, Loberg EM, Apricena F. The stress of being restrained induces brain damage after a hypoxic-ischemic insult in the 7 day old rat. Neuroreport 1996; (in press).

37 Kiyota Y, Pahlmark K, Memezawa H, Smith ML, Siesjo $B K$. Free radicals and brain damage due to transient middle cerebral artery occlusion - the effect of dimethylthiourea. Exp Brain Res 1993; 95: 388-96.

38 Lo EH, Steinberg GK, Panahian N, Maidment NT, Newcomb R. Profiles of extracellular amino acid changes in focal cerebral ischaemia - effects of mild hypothermia. Neurol Res 1993; 15: 281-7.

39 Busto R, Globus MYT, Dietrich WD, Martinez E, Valdes I, Ginsberg MD. Effect of mild hypothermia on ischemiainduced release of neurotransmitters and free fatty acids. Stroke 1989; 20: 904-10.

40 Bergstedt K, Hu BR, Wieloch T. Postischaemic changes in protein synthesis in the rat brain - effects of hypothermia. Exp Brain Res 1993; 95: 91-9.

41 Busto R, Dietrich WD, Globus MYT, Valdes I, Scheinberg $\mathrm{P}$, Ginsberg MD. Small differences in intraischemic brain temperature critically determine the extent of ischemic neuronal injury. $f$ Cereb Blood Flow Metab 1987; 7: 729-38.

42 Conradi NG, Muntzing $K$, Sourander $P$, Hamberger A. Effect of ambient temperature on rectal temperature in normal and malnourished rats during early postnatal development. Acta Physiologica Scandinavica 1984; 121: 147-53.

43 Abrahams R, Caton D, Clapp J, Barron DH. Thermal and metabolic features of life in utero. Clin Obstet Gynecol 1970; 13: 549-64.

44 Alfaro V, Peinado VI, Palacios L. Changes in plasma glucose, lactate, triglycerides and some non-protein nitroglucose, lactate, triglycerides and some non-protein nitrogen components induced by short-term hypothermia in the consci $149-55$.

45 Yager JY, Heitjan DF, Towfighi J, Vannucci RC. Effect of insulin-induced and fasting hypoglycemia on perinatal hypoxic-ischemic brain damage. Ped Res 1992; 31: 138-42.

46 Silverstein F, Buchanan K, Johnston MV. Pathogenesis of hypoxic-ischemic brain injury in a perinatal rodent model. Neurosci Lett 1984; 49: 271-7.

47 Andine P, Thordstein M, Kjellmer I, Nordborg C, Thiringer $\mathrm{K}$, Wennberg $\mathrm{E}$, Hagberg $\mathrm{H}$. Evaluation of brain damage in a rat model of neonatal hypoxicischemia. F Neurosci Methods 1990; 35: 253-60.

48 Lorek A, Takei Y, Cady E, Wyatt J, Penrice J, Edwards A, et al. Delayed ('secondary') cerebral energy failure following acute hypoxia-ischemia in the newborn piglet: continuous 48-hour studies by phosophorus magnetic resonance spectroscopy. Ped Res 1994; 36:
699-706.

49 Thoresen M, Penrice J, Lorek A, Wyatt J, Cady EB, Wylezinska $\mathrm{M}$, et al. Mild hypothermia following severe transient hypoxia-ischemia ameliorates delayed ('secondary') cerebral energy failure in the newborn piglet. Ped Res 1995; 5: 667-70. 